\title{
Tibet: Nationalisme blokerer for kulturel identitet
}

Erik Meier Carlsen

Urealistiske forestillinger om 'nationalitet' og 'demokrati' i moderne vestlig forstand blokerer for at opretholde tibetansk kulturs vitalitet og for dens mulighed for - på egne præmisser - at forny sig $\mathrm{i}$ takt med den kinesiske folkerepublik

Tibet er blevet en af vor tids mest velkendte fortællinger om national identitetsdannelse og selvstændiggørelse - selv om det er sket på præmisser, der sjældent har ladet et realistisk billede af processen og dens betingelser fremstå for betragteren.

Realiteten er, at Tibet aldrig - eller i hvert fald ikke de sidste 1000 år - har været en nationalstat, der på nogen måde kan sammenlignes med vores moderne, vestlige opfattelse af fænomenet, som indebærer et politisk, juridisk, territorialt og folkeligt fællesskab.

Det vidtstrakte tibetanske kulturområde er spredt ud over et kolossalt areal, som delvist er helt ubeboeligt. Resultatet er, at etnisk-kulturelle tibetanske befolkningsgrupper har beboet adskilte områder - om- kring store floder - af det store territorium og ikke siden sammenbruddet af det tibetanske, legendariske imperiale Yarlung-dynasti i 840 efter vor tidsregning har været underkastet en sammenhængende politisk styreform og lovgivning - før etableringen af Den Kinesiske Folkerepublik (PRC) i 1949-50

De adskilte tibetanske samfund, først og fremmest i Centraltibet og $\varnothing$ sttibet, har haft meget forskellig historie og helt forskellige relationer til de kinesiske kejserdynastier og den republikanske og senere kommunistiske kinesiske centralregering.

Vor tids al-tibetanske religiøse leder, Hans Hellighed Dalai Lama, har fra sit eksil i Indien søgt at repræsentere en sammenhængende 
tibetansk nation, der krævede selvstændighed, senere selvstyre, men som en samlet politisk enhed. Netop den manglende realisme i dette krav har efter alt at dømme været en afgørende blokering for, at den kinesiske centralregering og Dalai Lama har kunnet nå en forståelse, som kunne have bidraget til at beskytte tibetansk kultur og religion.

Dalai Lama har i flere omgange og med stigende klarhed accepteret, at Tibet nu og i al tænkelig fremtid er en del af den kinesiske folkerepublik, men han har insisteret på 'selvbestemmelse' gennem etablering af en form for vestligt liberalt demokrati, omfattende alle omkring seks millioner tibetanere, der i dag lever spredt og fordelt på 4-5 regioner i PRC. En sådan løsning forekommer ikke alene politisk urealistisk, men også praktisk uigennemførlig, og den kinesiske centralregering har kategorisk afvist den.

\section{Før Kina tog kontrol}

Indtil 1950, da den kinesiske hær tog kontrol med den del af det tibetanske kulturområde, der befinder sig nord for Himalayas bjerge, var det kulturelle Tibet et broget mønster af meget forskellige samfundstyper. Den mest kendte og spektakulære tibetanske samfundsdannelse var Lhasa-staten i Centraltibet, der var domineret af Dalai Lama-institutionen og det dermed forbundne magtcenter Ganden Paladset (gan- den phodrang), der siden det 17 . århundrede havde været en form for regering i det centrale Tibet - med aspirationer om at dominere hele det tibetanske kulturområde.

Ganden Paladset var en forlængelse af den form for hof, der i Tibet havde udviklet sig omkring de religiøse hierophanter, de såkaldte 'bevidst genfødte lamaer', på tibetansk tulku. Ganden Paladset var hoffet omkring Dalai Lama, en tulku inden for den reformerte gelugpa-skole, der gennem en nær forbindelse til krigeriske mongolske stammer mod nord var blevet en mægtig politisk faktor i Centraltibet. Den femte Dalai Lama og hans mongolske allierede overvandt midt i det 17 . århundrede Centraltibets hidtil dominerende religiøs-politiske magthaver og etablerede et nyt magtmonopol i det centrale Tibet, hvor Lhasa blev hovedstad og hjemsted for det legendariske Potala-palads. Gennem sine mongolske allieredes erobringer kom den femte Dalai Lama nærmere en genskabelse af det legendariske Yarlung-dynastis besiddelser end nogen anden tibetansk fyrste. Den femte Dalai Lamas død blev hemmeligholdt i en årrække, mens hans regent (der muligvis var hans illegitime søn) fastholdt magten, men herefter gik det voldsomt tilbage for Dalai Lamaernes kontrol.

I det folkerige Østtibet, hvor hovedparten af alle tibetanere bor omkring fire store nord-syd-strømmende floder, fik Dalai Lamaerne aldrig 
politisk magt af betydning. Dalai Lamaernes reliøse betydning nød bred anerkendelse, men de østtibetanske samfund udviklede sig i et broget mønster af selvstændige nomade- og bondesamfund, ofte små klosterstater med religiøse magtcentre og ofte under kontrol af kinesiske fyrster og krigsherrer med mere eller mindre løse bånd til den kinesiske centralregering.

Syd for Himalaya udviklede tibetanske kultur-samfund sig tilsvarende selvstændigt. Der opstod tibetanske 'kongeriger' i Lhadak, Khunu, Sikkim, (nu Indien) Khumbu, Mustang (Nepal) og Bhutan (selvstændigt).

\section{Kejserrigets kollaps}

I nyere tid kom den 13. Dalai Lama til at anføre en proces, der er blevet opfattet som en 'national selvstændiggørelse' af Tibet, efter en britisk invasion som 'erobrede' Lhasa i 1904. Ekspeditionen nedkæmpede effektivt den tibetanske modstand og gennemtvang en handelsaftale, der etablerede britiske handelscentre i Centraltibet. I de nærmest følgende år kollapsede det kinesiske kejserrige, og den 13. Dalai Lama søgte med halvhjertet britisk støtte at etablere en tibetansk selvstændighed.

Projektet mødte dog alvorlig modstand, dels fra den nye, republikanske kinesiske regering, dels fra en stærk konservativ og kinesisk-venlig fraktion blandt den monastiske poli- tiske elite i Lhasa og fra store dele af den tibetanske adel og verdslige godsbesiddere. Også den markante religiøse leder Panchen Lama, der med center i Tibets næststørste by Shigatse - styrede et næsten selvstændigt teokratisk samfund, kom i konflikt med den 13. Dalai Lama og flygtede til Kina, hvor han opnåede den republikanske regerings støtte. Den konservative, Kina-venlige fløj var dybt skeptisk over for den begyndende indtrængen af vestlig, europæisk kultur og ved alle tanker om styrkelsen af en 'national' stat, der truede det magtprivilegium, som hidtil reelt havde tilhørt tre gigantiske gelugpa-klostre omkring Lhasa, som kontrollerede Ganden Paladset.

Resultatet blev, at den 13. Dalai Lama måtte begrænse sine bestræbelser, og at han efter sin død umiddelbart blev afløst af en stærkt Kinavenlig regent (Reting), der sendte en ekspedition til det kinesisk-kontrollerede Østtibet, hvor den fandt en ny Dalai Lama-inkarnation i en kinesisk-talende tibetansk familie.

\section{Den nuværende Dalai Lama}

De første år under den nuværende Dalai Lamas opvækst blev præget af et blodigt opgør mellem den konservative Kina-venlige og den vestligt orienterede fraktion inden for den tibetanske elite i Lhasa.

Den vestligt orienterede fraktion vandt magten i nogle år, den tidligere regent og Dalai Lamas far blev 
myrdet efter en borgerkrigslignende opstand. Men da kommunisterne vandt magten i Tibet, og den sejrrige Folkets Befrielseshær rykkede ind i Østtibet lykkedes det den Kina-venlige fløj at gennemføre et fremrykket magtskifte, hvor den kun 15-årige Dalai Lama fik magten. Med den unge Dalai Lama i spidsen søgte den nu dominerende fløj i den tibetanske elite en forhandlingsløsning med den kinesiske centralregering, der omvendt viste sig villig til at lade den hidtidige feudale elite bevare deres magtpositioner i Centraltibet. Den tibetanske elites skepsis over for de antifeudale og religionsfjendtlige erobrere var dog stor nok til at meget store værdier allerede i 1950 blev deponeret i Indien.

Til gengæld var den unge Dalai Lamas personlige engagement i et åbent og tillidsfuldt forhold til den kinesiske centralmagt og specielt den karismatiske leder Mao Dzedong betydeligt.

I den sidste halvdel af 50'erne indledte den kinesiske centralregering en hårdhændet kommunisering af Østtibet og udløst dermed blodige opgør og store flygtningestrømme, som drog mod Lhasa og lejrede sig i tusindtal omkring hovedstaden. Den massive indvandring belastede Lhasas økonomi og forsyningssituation alvorligt og var en afgørende faktor i de tiltagende spændinger, der i 1959 førte til Dalai Lamas flugt.

Den eksilregering der blev etableret i Nordindien, var domineret af
Ganden Paladset og dermed en forlængelse af de tre store Gelugpaklostres magt. I de første år af eksilet kom det til betydelige magtkampe i det tibetanske eksilsamfund, hvor den unge Dalai Lama med tiltagende selvstændighed og myndighed satte sig igennem, idet han etablerede et nyt ideal om en tibetansk national enhed, på tværs af de forskellige sekter og det vidstrakte territorium, hvor de tibetanske kulursamfund havde hjemme.

Dalai Lamas selvstændighed og økumeniske, nationale ambition vandt stor tilslutning i det heterogene eksilsamfund, der talte flygtninge fra mange egne af kultur-Tibet. Til gengæld kan man sige, at der var tale om en ny form for national identitet, som aldrig før har eksisteret.

\section{Regering i eksil}

Efter Dalai Lamas flugt udviklede situationen i Tibet sig meget konfrontatorisk og polariseret, kulminerende med kulturrevoultionen, der over hele den kinesiske folkerepublik førte til blodige og destruktive overgreb på tradition, kultur og religion med mange tusinde ofre.

Men efter Maos død og Firebandens fald begyndte den kinesiske centralregering omkring 1980 at søge kontakt med Dalai Lama samtidig med at Tibet-politikken blev ændret, tibetanerne fik kulturelle og økonomiske særrettigheder og gen- 
opførelse af klostre og religiøst liv satte ind med stor styrke.

Den nye situation var en udfordring for eksilregeringen, men tilnærmelserne mødte vanskeligheder og midt i firserne indledte eksilregeringen en umådelig vellykket offensiv i den vestlige verden: Ny-buddhistiske, religiøse grupper i Vesten blev tilskyndet til at organisere sig i 'støttekomiteer' og 'kultursamfund' og markere sig politisk for den 'tibetanske sag', og Dalai Lama markerede sig med politiske taler i Washington og Europa-Parlamentet, hvor han tilbød en 'middelvej': Tibetansk selvstyre inden for kinesisk overhøjhed, idet han samtidig utvetydigt understregede ikke-volds-strategien.

Kampagnen i Vesten fik enorm succes der kulminerede, da Dalai Lama i 1989 fik Nobels fredspris. Samtidig udbrød der sporadiske demonstrationer i Centraltibet, hvor særligt Dalai Lama-loyale munke og nonner noget letsindigt udfordrede myndigheder med krav om 'Frit Tibet'.

\section{En ny Panchen Lama}

Den kinesiske Centralregering reagerede skarpt med arrestationer og fængslinger og krigsretstilstand. Den markante liberalisering der havde præget firserne, blev i nogen grad sat i stå i Centraltibet, mens Østtibet har nydt godt af en højere grad af frihed til kulturel og religiøs udfoldelse.
Midt i 90'erne var der tendenser til en ny åbning i forholdet mellem den kinesiske centralregering og eksillederen, men situationen blev tragisk belastet af et mislykket forsøg på at indsætte en ny inkarnation af Panchen Lama i 1995. De to tidligere Panchen Lama-inkarnationer havde fungeret i meget tæt alliance med den kinesiske centralregering, og den seneste inkarnation der blev i Tibet efter Dalai Lamas flugt, spillede en nøglerolle i genrejsningen af buddhismen siden 80'erne.

Da han døde i 1989, opstod der efter nogle års forvirring åbenbart et slags fælles ønske blandt Tibets ledende lamaer, den kinesiske centralregering og Dalai Lama om, at der kunne installeres en ny Panchen Lama med både Dalai Lamas og centralregeringens godkendelse. Projektet gik imidlertid galt på grund af gensidig mistillid, og da Dalai Lama imod traditionen og den fælles forståelse valgte ensidigt at bekendtgøre sin foretrukne kandidat, slog centralregeringen bak, fjernede Dalai Lamas kandidat fra offentlighedens søgelys og lod Tibets kinificerede religiøse institutioner udvælge en anden kandidat.

Konflikten har udløst en ny bølge polarisering, som har sat en ny tids religiøse ledere i Tibet under pres og igen gjort former for religiøs udfoldelse kontroversiel.

I 2000 forsøgte den kinesiske centralregering igen at etablere en forhandlingskontakt til Dalai Lama, ef- 
ter nogle iagttageres bedømmelse for at passivisere Tibet-spørgsmålet op til Kinas værtsrolle under de olympiske lege 2008. I de seneste otte år har der været seks forhandlingsmøder mellem Dalai Lamas udsendte og den kinesiske centralregering i Kina og Tibet. Men forhandlingerne har ikke ført til noget resultat.

\section{Blokering for forhandling}

En helt afgørende blokerende faktor synes fortsat at være eksil-regeringens krav om et samlet 'Stortibet' med et særligt, vestligt inspireret demokrati som styreform. Centralregering står fast på, at den kinesiske folkerepubliks forfatning allerede giver selvstyre til de etniske og kulturelle mindretal.

En meget problematisk konsekvens af de blokerede forhandlinger er konsekvenserne for den faktiske udvikling i Tibet. Konflikten med
Dalai Lama og eksilsamfundet synes fortsat at politisere dele af de buddhistiske aktiviteter i Tibet og nedtone regeringens ønsker om at give de nødvendige ressourcer og udfoldelsesmuligheder for tibetansk sprog, kultur og religion.

En nærliggende risiko synes at være, at urealistiske krav om 'nationalitet' og 'demokrati' i moderne, vestlig forstand, blokerer for helt afgørende muligheder for at opretholde den tibetanske kulturs buddhismes vitalitet og forudsætninger for på egne præmisser at forny sig i takt med den kinesiske folkerepubliks udvikling.

Erik Meier Carlsen er forfatter og journalist, politisk kommentator ved Dagbladet Information.

Artiklen er afleveret for urolighederne $i$ Tibet $i$ marts 2008. 